\title{
Know thyself
}

\section{A librarian uses the library}

\author{
by Amy Brunvand
}

$\mathrm{A}$

t a recent library conference, several speakers mentioned the need to know more about how and why university faculty and researchers use the library. In a way, this seems like a funny question-after all, why should the experience of doing research be radically different for librarians than for anyone else? Sure, we librarians have a slightly easier time figuring out the organization of the facility and material-we are the ones who put everything where it is in the first place-but the research process of locating, filtering, absorbing, and synthesizing information is hard for everyone. This hit home the last time I tried to write a paper. As an example of the real-life research experience, I present here, with only slight embarrassment, my research diary for a paper called "The Spread of Contra Dancing into New Communities" I presented at the American Folklore Society Annual Meeting in Pittsburgh, Pennsylvania, Oct. 17-20, 1996.

\section{Research diary for a paper}

Montb 1: I submit an abstract to a conference.

Month 2: Hooray! I got a letter saying that my abstract was accepted! Now I have six months to actually write the paper. I don't do anything about it immediately because I still have plenty of time.

Month 3: I pull stuff out of my personal files, bookshelf, and journals that might be useful. I check the library catalog and some journal abstracting databases and find many interesting-looking books, articles, and dissertations. The library has maybe half of them.
I check out a couple of books and start to read. I look up about ten articles in the journals we have at the library and find that only about two of them are actually useful and the rest are either off topic or content-free.

Montb 4-5: I order two articles and two dissertations from interlibrary loan. Several other articles might possibly be useful, but I'm not really sure so I don't bother with them. I figure I can get them later if I need to (but I never do). I interview two of my three sources. (One is in Europe until the end of the summer.) I scan three years of back issues of a newsletter to which I have a personal subscription (the library doesn't have it, and there is no index anyhow). At an event, I purchase a self-published book and talk to the friendly author about her research. The ILL dissertations arrive. Uh oh! They are both over 600 pages long and one is on microfilm and I only have two weeks to read them. It's not enough time! After they are already several weeks overdue ILL sends me a threatening note. I photocopy what I hope are all of the important sections and sheepishly give them back.

Montb 6: I look up some things that I found listed in the bibliographies of other things. In conversation, another librarian suggests an interesting passage in a book I read years ago and then forgot about. It's in Special Collections' locked case so I put off having a look. Finally, I take the time to look at it. Akkk! I need some more information on this subject. Another quick round of library research and digging stuff out of my per-

\section{About the author}

Amy Brunvand is access and outreach services librarian at the University of Utah; e-mail: abrunvan@library.utah.edu 
sonal library and files to fill the gap. It turns out some of the information is on the notes of several cassette tapes I own. I'm awestruck at how obscure my own sources are getting. I remember something related in a letter I read on a listserv three years ago. Aha! Someone put it on his Web page. Good thing, because I didn't keep a copy.

Montb 7: My third interviewee returns from Europe so I can interview her. A week before the conference I go into panic mode trying to condense all of this into a 20-minute talk. I haul my research notes and some books with me on the plane in case I need to add something at the last minute, (but it's just a security blanket. I never look at them). The morning before my talk I am still slightly adjusting the content of what I want to say because I have too much information and the talk is too long. Everything goes fine and a few people give me business cards so we can get in touch. I plan to write it up for publication.

\section{Research has its pitfalls-even for librarians}

What tickles me about this is that despite being a pretty good librarian I am as susceptible to the same pitfalls as every other library patron. I could blame it all on Hofstadter's law: "Everything always takes longer than you think it will, even if you take Hofstadter's law into account," but the sad fact is that research expands to fill the time available, regardless of how early you start. Luckily, our library has a generous renewal policy. Although I didn't really procrastinate all that badly, it still took an entire six months to complete the project. Still, the loan period was too short. I really did need to have all of this stuff on hand for six months. And during moments of panic, I was much less friendly and personable than usual, and I was inclined to feel selfish and willing to break rules.

It's only fair to point out that I was not starting from scratch as many students are when a professor assigns an arbitrary or notyet-familiar topic for a class project. In fact, I chose my subject because I already had lots of information and thought it would be easy to write up (which it was not particularly).

Librarians love indexes, but I used indexes as only part of my research strategy. For one thing, I already owned a collection of interesting stuff, and for another, a lot of it wasn't inclexed. Being part of a community of other people with similar interests was as important for me to get the information I needed as being adept at library research.

In any case, one major reason I needed to do library research was that I was afraid authors of similar papers would show up at the conference (which they did), and I didn't want to look like a fool in front of them. Good library research is partly a self-preservation device.

\section{Using ILL}

Using ILL is an especially interesting experience. If you have never done it for actual research purposes, you should give it a try. Don't get me wrong-I love ILL. I wouldn't have been able to finish the paper on time without it, and I've used ILL in the past to get my hands on things that otherwise would have been completely out of reach. However, remote access is no substitute for a handy collection. I wanted to know what articles existed, but I didn't necessarily want to read them all. When I started looking for journal articles there were plenty with interesting titles, but a lot of them didn't live up to their promise. If I had been trying to do the whole project through remote access, I suppose I would have had to order them all anyway, and then throw most of them out (and feel guilty about killing trees.)

And by the way, scholarly journal articles and dissertations are the only types of literature that are really well-indexed and abstracted. The other materials I was usingnewsletters, book fragments, tape recordings-are not in standard indexes or, as in the case of books, not indexed in much detail unless you have the book in hand. That makes it really hard to know what to request in the first place.

Surprisingly, the Internet did come through for me on this occasion, so I solemnly promise not to be as skeptical about its virtues as a research tool in the future.

Looking at my own behavior gives me a bit more compassion (if not actual forgiveness) for faculty members who say they always read a certain journal, but there is no evidence anyone ever touches the thing; who

(Know thyself continued on page 84) 
is by LC call number, though a Dewey number is also given as part of the citation.

Since $B C L$ is like the LC schedules illustrated, an ability to reasonably navigate through the schedules adds usefulness to this title. Even for one unfamiliar with the schedules, its separate volume of author and title indexes can be valuable for subject access if one knows a specific book that deals with the same subject that the client is seeking. It is up to the librarian to determine whether the possibility of a power failure makes it worthwhile to expend the time turning $B C L$ or something similar into the library's own union list by marking its contents against the library's holdings.

4) Likewise, make stack landmarks out of judiciously chosen, heavily-used reference sources. This is easiest in the case of megamultivolume sets because of their monumental visibility.

5) Small collections can act as schedules to larger collections. A library's ready reference collection could represent all the major subjects, such as business and literature. Titles could be added with this secondary use in mind.

6) Take the client in pursuit of a subject to Library of Congress Subject Headings and see if the subject has a call number, or if a related subject has one. At Rider College, the online catalog was down for an entire semester, and "the method chosen most frequently by students for locating books was by checking for the LC call number in the LCSH volumes." This probably should be expected, for the volumes offer a simple and brute means of finding books.

7) Keep a copy of the LC Classification Outline as handy as a flashlight and be acquainted with its general organization. Unfortunately, it has no keyword index. Supplement the Outline with a graphical library map locating the more significant classification letters and their subjects. This could be either a poster or a handout.

8) Even for those who have followed the Outline to the stacks, browsing for a specific subject among books can be a challenge, but it is occasionally possible to cheat. For example, large chunks of English (PR), American (PS), and other literatures are organized within chronological ranges (for example, the nineteenth century), then the authors are by alphabetical order. Knowing an author's nationality and century could eventually bring a dedicated browser to the appropriate number without reference to a catalog. The size of the collection would affect the outcome.

\section{Have a back-up plan ready}

Downtime in an online catalog should be rare. For example, at the Ward Edwards Library in January 1997 downtime was 0 percent; February .33 percent; and March 1.19 percent. This covered 24 hours daily, so the catalog could have been down when the library building was closed, thereby making this a non-problem for everyone except dial-in users. From November 1 to April 25, the library has been open 2,025 hours, during which time the system has been down six times, for a total of two hours and twenty-eight minutes, leaving an uptime of 99.88 percent. $^{2}$

Despite such reassuring figures, reference librarians should be Luddite enough to never depend solely on an online catalog. They should have a basic understanding of their library's classification scheme and be acquainted with the whereabouts of key books, which are not only important in themselves, but are fingerposts for browsing. There should always be a backup plan.

\section{Notes}

1. John Buschman, Kathryn Holden, and Dorothy Warner, "Coping without a catalog for a semester," CERL News 57, (April 1996): 223.

2. Figures from Information Services, Central Missouri State University.

(Know thyself cont. from page 81)

keep their library books too long and act possessive when asked to return them; who take library books along on out-of-town excursions; who refer students to the library for things that aren't there; who seldom use the expensive index bought just for them; and who freak out when they find out ILL will take a week or more to fill a request. In any case, a little self examination can provide insights to the experience of other researchers and help you as a librarian experience the library with the innocence that zen teachers call "beginner's mind." 